\title{
FUNGSI DEWAN PERWAKILAN RAKYAT DAERAH SEBAGAI UNSUR PENYELENGGARA PEMERINTAH DAERAH BERDASARKAN UNDANG - UNDANG NDMDR 23 TAHUN 2DI4 TENTANG PEMERINTAHAN DAERAH
}

\author{
Elita Tampubolon, 'Ranap Sitanggang, ${ }^{2}$ Haposan Siallagan ${ }^{3}$ \\ Fakultas Hukum Universitas HKBP Nammensen, Medan. \\ Program Magister Hukum Universitas HKBP Nommensen, Medan. \\ Dasen Fakultas Hukum dan Program Magister Hukum Universitas HKBP Nammensen, Medan. \\ E-Mail: elitatampubolon2704回gmail.com'
}

\begin{abstract}
Info Artikel
Diterima : 02 Maret 2020

Revisi : 17 April 2020

Terbit : :20 Juni 2020

\section{Key wards:}

DPRD, DPRD Function,

Administrating The Local

Government.
\end{abstract}

\section{Kata Kunci:}

DPRD, Fungsi DPRD,

Penyelenggaraan Pemerintahan Daerah.

\section{Corresponding Author :}

Elita Tampubolon, E-mail :

\begin{abstract}
Regional people's representatives council or abbreviated as DPRD is a representative positioned as an element of provincial/regencial administration in Indonesia.This council is directly elected by the society as the representation to take part in government implementation. the problems caused among the society are not the measurement that DPRD not organize its funtions but this is to help DPRD as the representative of saciety in administrating the local government.
\end{abstract}

\section{Abstrak}

Dewan Perwakilan Rakyat Daerah (disingkat DPRD) adalah lembaga perwakilan rakyat daerah yang berkedudukan sebagai unsur penyelenggara pemerintahan daerah di provinsi/kabupaten/kata) di Indonesia. Lembaga ini dipilih langsung oleh masyarakat sebagai wakil masyarakat untuk mengambil bagaian dalam penyelenggaraan pemerintah daerah. Masalah yang timbul di tengah masyarakat bukanlah menjadi tolak ukur bahwa DPRD tidak menjalankan fungsinya namun ini bertujuan untuk membantu DPRD lebih baik dalam fungsinya sebagai perwakilan rakyat dalam penyelenggaraan pemerintahan daerah. 


\section{PENDAHULUAN}

Pemerintah daerah memiliki kebebasan untuk mengelola urusan rumah tangga, sekaligus rakyat punya hak dan kebebasan untuk mengawasi bagaimana urusan rumah tangga dikelola. Pengawasan tersebut dilakukan secara formal melalui wakil-wakil mereka. Karena itu dalam rangka desentralisasi (otonom) di daerah, selain terdapat Kepala Daerah juga dibentuk Dewan Perwakilan Rakyat Daerah. Dilihat dari segi kedudukan Kepala Daerah, dalam konteks ini Kepala Daerah sebagai eksekutif utama di daerah bertanggung jawab kepada DPRD. '

Sebagai salah satu penyelenggara pemerintah daerah, di mata sebagian besar masyarakat luas Dewan Perwakilan Rakyat Daerah (DPRD) adalah tidak memiliki fungsi dan tidak nyata wujudnya. Karena bagi masyarakat lembaga ini hanya menguras uang negara saja dalam arti lain sering disebut makan gaji buta. Dengan banyaknya tanggapan demikian memunculkan rasa tidak percaya terhadap lemaga Dewan Perwakilan Rakyat Daerah yang kemudian munculnya rasa membenci kepada setiap anggota Dewan Perwakilan Rakyat Daerah karena tidak tau apa fungsi dari lembaga tersebut.

Perlu diketahui juga tanggapan yang menyatakan DPRD tidak memiliki fungsi tersebut tidak hanya menjadi tanggapan masyarakat saja, tapi di tengah mahasiswa/mahasiswi ini kerap di perdebatkan. Sehingga terjadinya pro-knntra yang tidak berujung dalam memperdebatkan hal ini yang sesungguhnya merupakan hal yang tidak bersifat positif kebenarannya.

Atas dasar pernyataan di atas harus diketahui juga sumber timbulnya pemikiran ini adalah karena adanya ketidak terbukaan DPRD akan fungsinya sebagai penyelenggara pemerintah daerah kepada masyarakat. Semestinya paradigma kekinian yang dibangun DPRD harus mampu mengusung konsep good governance, system penyelenggaraan pemerintahan bukan lagi disandarkan hanya pada penggunaan peraturan perundang-undangan semata, namun lebih dari itu bahwa penyelenggaraan pemerintahan yang baik sudah turut mempertimbangkan berbagai aspek, termasuk kemungkinan pentingnya keterlibatan eksternal demi membangun pemerintahan yang mampu menjawab kebutuhan rakyat secara transparan. ${ }^{2}$ Namun faktanya dapat dilihat dimana DPRD jarang sekali turun terjun ke masyarakat langsung untuk bersasialisai dan mendengar keluh kesah masyarakat yang sudah memberikan mandatnya kepada DPRD.

Pemikiran tersebut tidak dapat disalahkan karena wajar saja masyarakat berpikir demikian karena yang masyarakat ketahui DPRD berpihak kepada masyarakat. Pemahaman masyarakat akan DPRD tersebut juga sangat minim yaitu hanya sebatas mengetahui bahwa DPRD harus melakukan apa yang telah dijanjikan atau visiamisinya kepada masyarakat saat berkampanye pada saat pemilu.

Pertimbangan permasalahan itu juga didukung dengan sedikit penjelasan mengenai otonomi daerah yang dilaksanakan berdasarkan prinsip otonomi seluas-luasnya mengandung makna bahwa daerah diberikan kewenangan mengurus dan mengatur semua urusan rumah tangganya sendiri. Daerah otonom memiliki kewenangan membuat kebijakan daerah untuk memberi pelayanan, peningkatan peran serta, prakarsa, dan pemberdayaan masyarakat yang bertujuan untuk peningkatan kesejahteraan rakyat. Perumusan kebijakan daerah tersebut di antaranya adalah melalui peraturan daerah (Perda). Dengan demikian, posisi perda menjadi sangat penting sebagai bingkai legal dari kebijakan daerah.

\footnotetext{
'Dian Bakti Setiawan, Pemberhentian Kepala Daerah : Mekanisme Pemberhentian di Indanesia, (Jakarta : Rajawali Pers, 20II), hlm. 82.

2 Janpatar Simamora, Reformasi Birakrasi, Good Governance dan Etika Pelayanan Publik, Jurnal IImu Administrasi, STIA LAN Bandung. Volume X Nomor I, April 2013, hlm. I-2I.
} 
Disebutkan dalam pasal 14 UU №. 12 Tahun 20II yang berbunyi bahwa materi muatan Peraturan Daerah Provinsi dan Peraturan Daerah Kabupaten/Kota berisi materi muatan dalam rangka penyelenggaraan otonomi daerah dan tugas pembantuan serta menampung kondisi khusus daerah dan/atau penjabaran lebih lanjut Peraturan Perundang-undangan yang lebih tinggi. ${ }^{3}$

Selanjutnya berdasarkan sedikit penjelasan diatas maka pemahaman setiap masyarakat akan berbedabeda akan siapa yang akan atau harus mengambil sikap atas kewenangan membuat kebijakan daerah tersebut. Sehubungan dengan jamaknya problematika tentang hal ini sangat disayangkan apabila tidak ada yang menjadi narasumber yang benar untuk memberikan pemahaman yang benar dan jelas serta dapat dipahami secara umum kebenarannya.

Berikut akan dijelaskan juga pelaksanaan otanomi daerah yang didasarkan pada prinsip yang luas, nyata, dan bertanggung jawab mensyaratkan adanya tata kelola adanya pemerintahan yang baik. Suatu tata kelola pemerintahan yang baik mensyaratkan adanya transparansi dalam pengelolaan pemerintahan daerah, partisipasi yang aktif dari masyarakat dan akuntabilitas penyelenggaraan pemerintahan daerah. Dleh karena itu, untuk menciptakan tata kelola pemerintahan yang baik, seluruh elemen pemerintah daerah harus senantiasa mendorong penyelenggaraan pemerintahan daerahyang transparan, parsitipatif, dan akuntabel.

Salah satu dimensi penting dalam melihat penyelenggaraan tata pemerintahan yang baik di daerah adalah adanya tranparansi dalam penyelenggaraan pemerintahan daerah. Transparansi merupakan salah satu aspek mendasar bagi terwujudnya penyelenggaraan tata pemerintahan yang baik. Perwujudan tata pemerintahan yang baikmensyaratkan adanya keterbukaan, keterlibatan, dan kemudahan untuk mendapatkan akses bagi masyarakat terhadap proses pengambilan kebijakan publik. Penyelenggaraan pemerintahan daerah yang mengabaikan transparansi akan sangat sulit untuk menciptakan tata pemerintahan yang baik.

Penyelenggaraan pemerintahan yang transparan semakin menjadi tuntutan dalam penyelenggaraan pemerintahan daerah. Penyelenggaraan pemerintahan yang transparan merupakan upaya membuat pengambilan kebijakan publik yang menyangkut berbagai aspek, diharapkan lebih banyak melibatkan masyarakat.

Transparansi penyelenggaraan pemerintah daerah adalah mekanisme publik yang memiliki akses informasi terhadap proses jalannya pemerintah daerah. Secara umum, transparansi dalam penyelenggaraan akan menekan terjadinya praktik korupsi, kolusi, dan nepotisme di tingkat birokrasi lokal. Keterbukaan birokrasi di daerah terdapat penyelenggaraan pemerintahan yang dilaksanakannya merupakan itikad untuk menciptakan goad and clean government.

Dalam pelaksanaan otonomi daerah di era reformasi ini, rendahnya transparansi seringkali disebabkan perbedaan persepsi dari actor pelaksana otonomi daerah. Seringkali pemerintah daerah menganggap transparansi bukan merupakan kebutuhan yang perlu dilaksanakan. Pada praktik penyusunan anggaran, pemerintah daerah sering menganggap prosesnya cukup transparan ketika sidang penetapan dan anggaran pendapatan daerah ditetapkan secara terbuka, sedangkan hasil penetapan tertulis tidak dapat dikonsums pihak luar. Pemerintah daerah sering kali menganggap dokumen anggaran pendapatan dan belanja daerah merupakan dokumen yang harus dijaga kerahasiaannya. Pada hakikatnya dokumrn anggaran tersebut merupakan tolak ukur terhadap kinerja penyelenggaraan pemerintahan daerah.

\footnotetext{
${ }^{3}$ Putera Astomo, IImu Perundang-undangan : Teari dan Praktek di Indonesia, (Depok: Rajawali Pers, 20I8), hlm.69-70. 
Suatu tata kelola pemerintahan daerah yang baik tidak hanya membutuhkan pelaksanaan pemerintah secara transparan, tetapi juga partisipasi dari masyarakat. Partisipasi masyarakat merupakanfaktor yang penting dalam pelaksanaan otonomi daerah. Partisipasi masyarakat harus dipahami sebagai wujud keterwakilan (representativeness) produk kebijakan. Partisipasi masyarakat itu dapat diwujudkan (representative) melalui proses pemilihan (e/ection) yang baik, sehingga peranan masyarakat dapat dilihat dari perwujudan peran DPRD di dalam mengawasi pelaksanaan kebijakan oleh kepala daerah.

Tingkat akuntabilitas pemerintah daerah dapat diukur dengan tingkat pelayanan yang diberikan kepada masyarakat. Pelayanan publik merupakan kata kunci dalam pelaksanaan otonomi daerah karena secara esensial otonomi daerah adalah milik masyarakat daerah. Oleh sebab itu otonomi daerah harus dijalankan oleh Pemerintah Daerah dan dipertanggung jawabkan kepada masyarakat khususnya dari segi kualitas pelayanan publik yang disediakan untukmasyarakat. Masyarakat daerah memberikan legitimasi politik kepada wakil rakyat yang dipilih dalam pemilu untuk mewakili aspirasi masyarakat guna menciptakan kesejahteraannya. Tingkat kesejahteraan akan terkait erat dengan tingkat pelayanan yang disediakan Pemerintah Daerah kepada rakyat, baik secara kualitatif maupun kuantitatif. ${ }^{4}$ Berdasarkan masalah-masalah tersebut peneliti akan melakukan penelitian melalui buku-buku untuk memberikan pemahaman kepada masyarakat akan fungsi, tugas dan tanggung jawab DPRD dan akan memberikan sedikit solusi kepada DPRD dalam menjalankan fungsi, tugas dan haknya. Berdasarkan batasan masalah yang sudah dikemukan, maka rumusan masalah dalam penelitian ini adalah :

1. Apa fungsi, tugas ,tanggung jawab serta hak dan kewajiban DPRD?

2. Apa solusi mengatasi persoalan hubungan antara masyarakat dan DPRD?

\section{PEMBAHASAN}

Undang- Undang Nomor Z2 Tahun 1999 secara tegas menyatakan DPRD sebagai badan legislatif daerah, sedangkan pemerintah daerah yang terdiri dari atas kepala daerah dan perangkat daerah lainnya sebagai badan eksekutif daerah. DPRD sebagai badan legislatif daerah berkedudukan sama dengan mitra pemerintah daerah. Dalam UUD 1945, kedudukan DPRD juga diakui secara tegas. Sehubungan dengan itu, Indonesia sebagai negara hukum yang telah ditegaskan dalam ketentuan Pasal I ayat (3) UUD NRI 1945 seyggianya harus sepenuhnya menjalankan roda pemerintahan berdasarkan ketentuan hukum yang telah digariskan dalam konstitusi. Sebagaimana dikemukakan Janpatar Simamora dan Bintang ME Naibaho bahwa The country of Indanesia is a country of law. This is confirmed in section I paragraph (3) of the 1945 Canstitution of the Republic of Indonesia. As a consequence of the adaption of a state of law for the Indanesian nation, all state and government activities must truly refer to existing legal rules. The emergence of ideas and thaughts of the rule of law is inseparable from the pattern of implementing state power that is vulnerable to arbitrary acts, so it is necessary to limit state power through legal instruments. ${ }^{B}$ Dalam rangka menerapkan apa yang diatur dalam Uلا 1945, jika ditemukan adanya kesulitan dalam memaknainya, maka dapat dilakukan melalui penafsiran kanstitusi. The

\footnotetext{
${ }^{4}$ Hari Sabarno, Memandu Dtanami Daerah Menjaga Kesatuan Bangsa, (Jakarta : Sinar Grafika, 2007), hlm.37-40.

5 Jampatar Simamora, Urgensi Keberadaan GBHN dalam Sistem Ketatanegaraan Republik Indanesia, Jurnal Litigasi, Volume 17 Nomar 2 Tahun 2016, 3440-3441.

6 Janpatar Simamara dan Bintang ME Naibaho., Statutary of The Republic of Indanesia Witness As a Gavernment Institutian Implementing Cauntry's Pawer in The Indanesian State Cancerns System, Proceedings of the First Nommensen International Canference on Creativity \& Technolagy, NICCT, 20-Z1 September 2019, Medan, North Sumatera, Indanesia.
}

Fungsi Dewan Perwakilan Rakyat Daerah Sebagai Unsur Penyelenggara Pemerintah Daerah Berdasarkan Undang - Undang Nomar 23 Tahun 2014 Tentang Pemerintahan Daerah 
interpretation of the constitution is a methad used in arder to find the true meaning of each provision in the constitution through legal discavery effarts (rechtsvinding) based an the basic law af a cauntry. ${ }^{7}$ Dengan demikian, tidak ada alasan untuk mengatakan tidak menjalankan ketentuan UUD 1945 dikarenakan tidak jelasnya rumusan dalam UلD.

Di atas telah disebutkan bahwa pemerintah daerah terdiri dari kepala daerah beserta perangkat daerah lainnya.hal ini dapat diartikan bahwa DPRD bukan merupakan bagian dari pemerintahan daerah, sedangkan urusan pemerintahan yang diserahkan kepada daerah otonom adalah urusan pemerintahan yang menjadi kampetensi pemerintah. Oleh karena itu dalam penyelenggaraan daerah tidak dikenal dengan adanya lembaga legislatif maupun lembaga yudikatif. Hal ini bermakna bahwa pemerintah daerah terdiri atas kepala daerah dan DPRD.

DPRD sebagai badan legislatif daerah berkedudukan sejajar dan menjadi mitra pemerintah. Pengertian mitra dan sejajar diartikan mempunyai hak dan kewajiban yang sama tetapi kontradiksi dengan pernyataan bahwa kepala daerah bertanggung jawab kepada DPRD.

Dalam pada itu, DPRD sebagai Badan Legislatif Daerah berkedudukan sejajar dan menjadi mitra pemerintah daerah. Dalam implementasinya ada kecenderungan DPRD menuntut hak yang sama dengan eksekutif terutama dalam hal mendapatkan alokasi anggaran di dalam APBD. Penafsiran yang sesungguhnya adalah pengertian sejajar dan mitra yang selalu dalam konteks kelembagaan dan upaya check and balance antara DPRD dengan Eksekutif dalam rangka mewujudkan sistem pemerintahan yang sehat dan baik. ${ }^{8}$

Kedudukan DPRD Provinsi adalah lembaga perwakilan rakyat daerah provinsi, yang merupakan wahana untuk melaksanakan Demokrasi .Kedudukan DPRD Pravinsi dengan gubernur sebagai kepala eksekutif pemerintah pravinsi adalah sejajar. Keduanya adalah mitra sejajar. Artinya DPRD Pravinsi bukan bagian dari gubernur, bukan bawahan, bukan atasannya. Keduanya adalah mitra sejajar yang bersama-sama menciptakan pemerintahan yang efisien, efektif, dan transparan dalam rangka memberikan pelayanan publik yang memuaskan demi terciptanya kesejahteraan masyarakat di daerah.

DPRD Kabupaten adalah lembaga yang mewakili rakyat daerah kabupaten yang bersangkutan. Anggata DPRD Kabupaten dipilih dari partai politik dalam pemilu. Kedudukan, fungsi, susunan, hak dan kewajiban, alat kelengkapan, dan hubungan dengan rakyat dan kepala daerah sama dan sebangun dengan yang dimiliki DPRD Provinsi. Yang membedakan hanya ruang lingkupnya saja, yaitu pada ruang lingkup kabupaten.

DPRD Kota adalah lembaga yang mewakili rakyat daerah kota yang bersangkutan. Sama halnya dengan DPRD Kabupaten, anggata DPRD Kota juga dipilih melalui pemilu. Para anggata DPRD Kota mewakili kotanya. Kedudukan, fungsi, susunan, hak, dan kewajiban, alat kelengkapan, dan hubungannya dengan rakyat dan kepala daerah sama dan sebangun dengan yang dimiliki DPRD Provinsi dan Kabupaten. Yang membedakan hanya ruang lingkupnya saja, yaitu pada ruang lingkup kata. ${ }^{\text {' }}$

\footnotetext{
${ }^{7}$ Janpatar Simamara, Development of Constitutional Interpretation by Canstitutional Caurt of Indanesia in the Context of State Institutions' Authority Dispute Settlement, IDSR Journal Of Humanities And Social Science (IDSR-JHSS) Volume 24, Issue I2, Series. 3 (December. 2019) 45-54.

${ }^{8}$ HaW Widjaja, Penyelenggaraan Dtonomi Di Indonesia : Dalam Rangka Sasialisasi Undang-Undang Nomor 32 Tahun 2004 tentang Pemerintahan Daerah, (Jakarta : PT Raja Grafindo Persada, 2005), hlm.53-55.

${ }^{9}$ Hanif Nurcholis, Teari dan Praktik Pemerintahan dan Dtonomi Daerah, (Jakarta : PT. Grasinda, 2005), hlm. 219-225.
}

Fungsi Dewan Perwakilan Rakyat Daerah Sebagai Unsur Penyelenggara Pemerintah Daerah Berdasarkan Undang - Undang Nomar 23 Tahun 2014 Tentang Pemerintahan Daerah 
Berdasarkan beberapa penjelasan di atas dapat disimpulkan bahwa DPRD memiliki kedudukan yang sama dengan pemerintah daerah dan merupakan lembaga perwakilan rakyat daerah dan berkedudukan sebagai unsur penyelenggara pemerintahan daerah.

Pada hakikatnya, urusan pemerintah yang diserahkan kepada daerah otonam merupakan urusan pemerintah yang yang menjadi kopetensi pemerintah (eksekutif). Dleh karena itu dalam penyelenggaraan pemerintahan daerah tidak dikenal lembaga legislatif maupun lembaga yudikatif. Istilah Dadan Legislatif Daerah tidak dipakai untuk sebutan Dewan Perwakilan Rakyat Daerah (DPRD), seperti Trias Palitika, Montesquieu yang membagi kekuasaan negara dalam kekuasaan legislatif, eksekutif, yudikatif.

Dengan demikian, DPRD tidak mempunyai legislasi, melainkan fungsi, yaitu pengaturan, penganggaran, dan pengawasan atas pelaksanaan kebijakan daerah yang dijalankan oleh kepala daerah (gubernur, bupati, walikata). Dengan demikian yang menjadi fungsi utama dari DPRD adalah melakukan pengawasan/cantral terhadap pelaksanaan kebijakan daerah. ${ }^{10}$

Setelah mengetahui kedudukan DPRD sebagai penyelenggara pemerintah daerah dapat di ambil kesimpulan bahwa fungsi dari DPRD adalah sebagai penyelenggara pemerintah daerah yang merupakan wakil rakyat yang mewakili dalam menyampaikan segala aspirasi masyarakat. Namun dapat juga dinyatakan bahwa DPRD adalah lembaga yang mengayami masyarakat daerahnya agar dapat disebut bahwa masyarakat mengambil bagian dalam penyelenggaraan pemerintahan. Harus diketahui pula bahwa fungsi darp DPRD itu sendiri ada 3 (tiga), yaitu legislasi, anggaran, dan pengawasan.

Dalam menjalankan tugas dan kewenangannya sebagai Kepala Daerah, Gubernur bertanggung jawab kepada DPRD Provinsi. Adapun Kepala Daerah Kabupaten disebut Bupati, dan Kepala Daerah Kota disebut Walikota. Dalam menjalankan tugas dan kewenangan selaku Kepala Daerah, Kepala Daerah bertanggung jawab kepada DPRD Kabupaten/Kota.

Di setiap akhir tahun anggaran, Kepala Daerah wajib menyampaikan pertanggungjawaban kebijakann kepada DPRD. Apabila ditolak pertanggungjawabkannya, baik pertanggungjawaban kebijakan pemerintah maupun pertanggungjawaban, harus melengkapi dan/atau menyempurnakannya dalam jangka waktu paling lama tiga puluh hari. Bagi Kepala Daerah yang pertanggungjawabannya ditolak untuk kedua kalinya, DPRD dapat mengusulkan pemberhentiannya kepada Presiden "

Untuk mewujutkan fungsi dari DPRD maka berikut yang menjadi tugas DPRD adalah sebagai berikut :

a) Membentuk Perda yang dibahas dengan kepala daerah untuk mendapat persetujuan bersama;

b) Membahas dan mewujudkan rancangan Perda tentang APBD bersama dengan kepala daerah;

c) Melaksanakan pengawasan terhadap pelaksanaan Perda, dan peraturan perundang-undangan lainnya, peraturan kepala daerah, APBD, kebijakan pemerintah daerah dalam melaksanakan program pembangunan daerah, dan kerjasama internasionalal daerah;

d) Mengusulkan pengangkatan dan pemberhentian kepala daerah/wakil kepala daerah kepada Presiden melalui Menteri Dalam Negeri, melalui Gubernur bagi DPRD Kabupaten/Kota;

e) Memilh wakil kepala daerah dalam hal terjadi kekosongan jabatan wakil kepala daerah;

${ }^{10}$ HAW Widjaja, Penyelenggaraan Dtonomi Di Indanesia : Dalam Rangka Sasialisasi Undang-Undang Nomor 32 Tahun 2004 tentang Pemerintahan Daerah, (Jakarta : PT Raja Grafindo Persada, 2005), hlm.52.

" J. Kaloh, Kepemimpinan Kepala Daerah: Pala Kegiatan, kekuasaan, dan Perilaku Kepala Daerah dalam Pelaksanaan Dtonami Daerah, (Jakarta : Sinar Grafika, 2010), hlm. 35-36 
f) Memberikan pendapat dan pertimbangan kepada pemerintah daerah terhadap rencana perjanjian internasional di daerah;

g) Membentuk panitia pengawas pemilihan kepala daerah;

h) Melakukan pengawasan dan meminta laparan KPUD dalam penyelenggaraan pemilihan kepala daerah;

i) Memberikan persetujuan terhadap rencana kerja sama antar daerah dan dengan pihak ketiga yang membebani masyarakat dan daearah. ${ }^{12}$

Selain tugas DPRD juga mempunyai hak dan kewajiban sebagai salah satu penyelenggara pemerintah daerah, antara lain, sebagai berikut :

a) Membuat peraturan daerah serta membuat dan menetapkan APBN bersama-sama dengan kepala daerah.

b) Masing-masing anggata DPRD mempunyai hak-hak tertentu, seperti hak mengajukan pendapat, meminta keterangan, prakarsa, dan mengadakan penyelidikan.

Kewajiban DPRD adalah sebagai berikut:

a) Mempertahankan, mengamankan, serta mengamalkan Pancasila dan ULD 1945.

b) Menjunjung tinggi dan melaksanakan GBHN dan ketetapan-ketetapan MPR lainnya secara kansekuen, serta menaati segala perundang-undangan yang berlaku.

г) Bersama-sama kepala daerah menyusun serta menetapkan APBD dan peraturan-peraturan daerah untuk kepentingan daerah dalam batas-batas wewenang yang diserahkan kepada daerah atau melaksanakan peraturan perundang-undangan yang pelaksanaannya dituskan kepala daerah.

d) Memperhatikan aspirasi dan memajukan tingkat kehidupan rakyat dengan berpegang kepada program pembangunan pemerintah. ${ }^{13}$

Hak dan kewajiban DPRD berdasarkan (Pasal 43 dan 44 Uل U2/2004), berikut yang menjadi hak DPRD :

a) Interpelasi, yaitu hak untuk meminta keterangan kepada kepala daerah mengenai kebijakan pemerintah daerah yang penting dan strategis yang berdampak luas pada kehidupan masyarakat, daerah dan negara.

b) Angket, yaitu hak melakukan penyelidikan terhadap suatu kebijakan tertentu Kepala Daerah yang pentig strategis serta berdampak luas pada kehidupan masyarakat, daerah dan negara yang digunakan bertentangan dengan peraturan dan undang-undang. Hak angket ini dilaksanakan setelah dilakukan iterpelasi dan mandate persetujuan Rapat Paripurna DPRD yang dihadiri sekurang-kurangnya 3/4 jumlah anggota dan putusan diambil dengan persetujuan sekurang-kurangnya 2/3 dari jumlah anggata DPRD yang hadir.

c) Menyatakan pendapat tentang kebijakan dan implementasi kebijakan oleh kepala daerah.

d) Mengajukan rancanagn Peraturan Daerah

e) Mengajukan pertanyaan

f) Menyampaikan usul dan pendapat

g) Memilih dan dipilih

h) Membela diri

i) Imunitas

${ }^{12}$ H. Siswanta Sunarno, Hukum Pemerintahan Daerah di Indanesia, (Jakarta : Sinar Grafika, 2009), hlm. 67-68. ${ }^{13}$ C.S.T.Kansil, Christine S.T. Kansil, Sistem Pemerintahan Daerah, (Jakarta : PT. Bumi Aksara,2005), hlm. 145-146. 
j) Protakoler

k) Keuangan dan Administrasi

Yang menjadi kewajiban anggata DPRD berdasarkan (Pasal 45 Lل No. 32/2004) adalah:

a) Mengamalkan pancasila, melaksanakan UUD RI 1945 dan menaati segala peraturan perundangundangan.

b) Melaksanakan kehidupan demokrasi dalam penyelenggaraan pemerintahan daerah

c) Mempertahankan dan memelihara kerukunan nasional serta keutuhan NKRl.

d) Memperjuangkan peningkatan kesejahteraan rakyat di daerah.

e) Menyerap, menampung, menghimpun dan menindaklanjuti aspirasi masyarakat.

f) Mendahulukan kepentingan negara diatas kepentingan pribadi, kelompok dan golongan.

g) Memberikan pertanggungjawaban atas tugas dan kinerjanya selaku anggata DPRD sebagai wujud tanggungjawab moral dan politis terhadap daerah pemilihannya.

h) Menaati Tata Tertib. Kode etik dan sumpah/ janji anggota DPRD

Menjaga narma dan etik dalam hubungan kerja dengan lembaga yang terkait. ${ }^{14}$

Sebagai masyarakat yang bijaksana harus mengetahui Undang-Undang menentukan bahwa pemerintah lokal menggunakan nomenlatur "Pemerintah Daerah". Pemerintah lokal terdiri dari : Legislatif Dewan Perwakilan Rakyat Daerah (DPRD). Eksekutif Dewan Pemerintah Daerah (DPD). DPRD mengatur dan mengurus rumahtangga daerahnya. Anggata DPRD dipilih dalam sebuah pemilihan yang diatur oleh Undang-Undang pembentukan daerah. Masa jabatan anggata DPRD lima tahun. ${ }^{15}$

Dewan Perwakilan Rakyat Daerah (disingkat DPRD) adalah lembaga perwakilan rakyat daerah yang berkedudukan sebagai unsur penyelenggara pemerintahan daerah di provinsi/kabupaten/knta) di Indanesia. DPRD disebutkan dalam UUD 1945 pasal 18 ayat 3: "Pemerintahan daerah pravinsi, daerah kabupaten, dan kota memiliki Dewan Perwakilan Rakyat Daerah yang anggota- -anggatanya dipilih melalui pemilihan umum". DPRD kemudian diatur lebih lanjut dengan undang-undang, terakhir melalui Undang-Undang Nomar 17 Tahun 2014. ${ }^{16}$ Penting untuk mengetahui lebih lanjut mengenai apa yang menjadi fungsi, tugas, hak dan kewajiban, dari DPRD yang disebutkan dan dijelaskan Undang-Undang Republik Indanesia Nomar 7 Tahun 2014 tentang Majelis Permusyawaratan Rakyat, Dewan Perwakilan Rakyat, Dewan Perwakilan Daerah,dan Dewan Perwakilan Rakyat Daerah.

Penyelenggara memiliki 2 arti. Penyelenggara berasal dari kata dasar selenggara. Selenggara berasal dari kata dasar menyelenggarakan yang berarti menunaikan atau menyampaikan (maksud, cita-cita, harapan, tugas kewajiban, dan sebagainya). Penyelenggara adalah sebuah homonim karena arti-artinya memiliki ejaan dan pelafalan yang sama tetapi maknanya berbeda. Penyelenggara memiliki arti dalam kelas nomina atau kata benda sehingga penyelenggara dapat menyatakan nama dari sesearang, tempat, atau semua benda dan segala yang dibendakan. Arti kata penyelenggara adalah pemelihara. Penyelenggara juga berarti pemiara. ${ }^{17}$

\footnotetext{
${ }^{14}$ Arenawati, Administrasi Pemerintahan Daerah Sejarah, Konsep, dan Penatalaksana di Indonesia, (Yogyakarta : Graha llmu, 2016), hlm. $65-66$.

${ }^{15}$ Sarman, Mohammad Taufik Makarao, Hukum Pemerintah Daerah di Indanesia, (Jakarta : Rineka Cipta, 20II), hlm. IG.

16 Wikipedia bahasa Indanesia, ensiklopedia bebas," Dewan Perwakilan Rakyat Daerah", https://id.wikipedia.org , wiki , Dewan_Perwakilan_Rakyat_Daerah, (diakses pada 4 Uktober 2019, pukul 22.II).

${ }^{17}$ Arti Kata Penyelenggara Di Kamus Besar Bahasa Indanesia (KBBI) - Lektur.ID, https://lektur.id/arti-kata/penyelenggara.html.
}

Fungsi Dewan Perwakilan Rakyat Daerah Sebagai Unsur Penyelenggara Pemerintah Daerah Berdasarkan Undang - Undang Nomar 23 Tahun 2014 Tentang Pemerintahan Daerah 
Undang- Undang Nomor 23 Tahun 2014 tentang Pemerintahan Daerah, Pasal I sampai dengan pasal 50 dijelaskan mengenai susunan atau pembagian dan cakupan batasan tugas dan tanggung jawab pemerintah dari pemerintahan pusat sampai pemerintahan daerah. ${ }^{18}$

Dengan demikian di atas menjelaskan siapa dan apa DPRD tersebut dalam Pemerintahan Daerah Indonesia disertai dengan tugas dan tanggung jawab dari DPRD itu sendiri. Namun tidak heran masalah yang muncul di tengah masyarkat saat ini mengenai ketidak tahuan atau dapat juga disebut tidak mempercayai akan keberadaan DPRD sebagai wakil mereka. Hal ini tidak dapat dinyatakan semerta-merta yang menjadi masalahnya adalah masyarakat itu sendiri dan tidak dapat juga dinyatakan DPRD bersalah dalam masalah ini.

Berikut harus diketahui yang pertama dan utama adalah masyarakat harus tahu dengan benar bahwa dalam Pemerintahan Daerah adalah wakil dari masyarakat itu sendiri dalam proses penyelenggaraan pemerintahan daerah. Dasar pendapat ini muncul agar dalam berkomentar masyarakat memang tahu dan paham apa yang menjadi tuntutan mereka akan ketidak adilan yang dirasakan atas posisinya sebagai masyarakat yang sudah memberikan kepercayaan kepada DPRD yang terpilih. Karena diketahui banyak dari masyarakat yang tidak tahu dengan keberadan DPRD itu sendiri sebagai wakil mereka memiliki tanggung jawab seperti apa. Namun tidak dapat diabaikan bahwa asap muncul karena ada api berarti masyarakat merasa tidak percaya kepada DPRD sendiri karena adanya masalah yang dianggap tidak masalah oleh DPRD.

\section{PENUTUP}

Di tengah era globalisasi ini masyarakat sudah mulai berpikir kritis sehingga pemerintah dan terutama DPRD yang dibahas saat ini harus tanggap dengan situasi masyarakat yang demikian. Artinya DPRD harus tahu apa yang menjadikan masyarakat menjadi tidak percaya akan permasalahan yang telah dibahas di bagian pendahuluan, dapat disimpilkan yang menjadi masalah utama adalah ketidak terbukaan DPRD dalam menjalankan fungsi, tugas dan kewajbannya serta tanggung jawabnya sebagai wakil masyarakat daerah.

Hubungan antara masyarakat luas dan DPRD tang tidak baik karena adanya kesalah pahaman yang harus di selesaikan terlebih dahulu. Dengan demikian untuk mencapai penyelenggaraan pemerintahan yang baik maka haruslah diselesaikan permasalahan yang ada antara masyarakat dan DPRD mengenai fungsi dan kedudukan daripada DPRD dalam penyelenggaraan pemerintahan daerah.

Di setiap permasalahan di atas maka peran yang paling dibutuhkan untuk mengambil sikap adalah DPRD karena lembaga tersebut merupakan wakil rakyat untuk menerima segala aspirasi masyarakat. Secara singkat dapat dinyatakan bahwa DPRD harus melakukan program khusus pendekatan kepada masyarakat untuk mewujudkan hubungan yang baik dan melakukan transparansi kepada masyarakat akan fungsi, tugas dan tanggung jawabnya sehingga masyarakat mengetahuinya dengan luas akan hal itu. Hal ini dapat dilakukan sama halnya dengan pada saat melakukan kampanye. DPRD juga dapat melakukan penyuluhan- penyuluhan ke setiap daerah-daerah bagiannya untuk mengembangkan pemikiran masyarakat dan menunjang kwalitas berpikir masyarakat yang positif.

\section{DAFTAR PUSTAKA}

Arenawati. 2016. Administrasi Pemerintahan Daerah Sejarah, Konsep, dan Penatalaksana di Indanesia. Yogyakarta : Graha llmu.

${ }^{18}$ Undang- Undang Nomar 23 Tahun 2014 tentang Pemerintahan Daerah.

Fungsi Dewan Perwakilan Rakyat Daerah Sebagai Unsur Penyelenggara Pemerintah Daerah Berdasarkan Undang - Undang Nomar 23 Tahun 2014 Tentang Pemerintahan Daerah 
Arti Kata Penyelenggara Di Kamus Besar Bahasa Indonesia (KBBI) Lektur. ID, https://lektur.id/artikata/penyelenggara.html.

Astomo, Putera. 2018. IImu Perundang-undangan : Teari dan Praktek di Indonesia Depok: Rajawali Pers.

Christine S.T Kansil dan C.S.T. Kansil . 2005. Sistem Pemerintahan Daerah. Jakarta: PT. Bumi Aksara.

Ensiklopedia bebas, Wikipedia bahasa Indanesia, " Dewan Perwakilan Rakyat Daerah", https://id.wikipedia.org > wiki > Dewan_Perwakilan_Rakyat_Daerah, diakses pada 4 Dktober 2019, pukul 22.II.

Simamara, Janpatar. "Reformasi Birokrasi, Good Gavernance dan Etika Pelayanan Publik." لJurna/ Ilmu Administrasi: Media Pengembangan Ilmu dan Praktek Administrasi, 10, №. I (2013): 39-60.

Simamora, Janpatar., Urgensi Keberadaan GBHN dalam Sistem Ketatanegaraan Republik Indanesia, Jurnal Litigasi, Volume 17 Nomar 2 Tahun 2016, 3440-3441.

Simamara, Janpatar dan Naibaho, Bintang ME, Statutary of The Republic of Indonesia Witness As a Gavernment Institution Implementing Cauntry's Power in The Indanesian State Cancerns System, Proceedings of the First Nommensen International Conference on Creativity \& Technology, NICCT, 20-2I September 2019, Medan, North Sumatera, Indanesia.

Simamora, Janpatar., Deve/opment of Constitutional Interpretation by Constitutional Court of Indonesia in the Context of State Institutions' Authority Dispute Settlement, IUSR Journal Of Humanities And Social Science (IDSR-JHSS) Volume 24, Issue I2, Series. 3 (December. 2019) 45-54.

Kaloh, 」. 20I0. Kepemimpinan Kepala Daerah : Pola Kegiatan, kekuasaan, dan Perilaku Kepala Daerah dalam Pelaksanaan Dtonomi Daerah. Jakarta : Sinar Grafika.

Mohammad Taufik Makarao dan Sarman. 201I. Hukum Pemerintah Daerah di Indanesia. Jakarta : Rineka Lipta.

Nurcholis, Hanif. 2005. Teari dan Praktik Pemerintahan dan Dtanomi Daerah. Jakarta : PT. Grasindo.

Sabarno, Hari. 2007. Memandu Dtonami Daerah Menjaga Kesatuan Bangsa. Jakarta : Sinar Grafika.

Setiawan, Dian Bakti. 20ll. Pemberhentian Kepala Daerah : Mekanisme Pemberhentian di Indonesia. Jakarta : Rajawali Pers.

Sunarno, H. Siswanto. 2009. Hukum Pemerintahan Daerah di Indonesia. Jakarta: Sinar Grafika.

Undang- Undang Nomar 23 Tahun 2014 tentang Pemerintahan Daerah

Widjaja, HAW. 2005. Penyelenggaraan Dtonomi Di Indanesia : Dalam Rangka Sosialisasi Undang-Undang Nomor 32 Tahun 2004 tentang Pemerintahan Daerah. Jakarta : PT Raja Grafinda Persada. 